\title{
Erratum to: Efficient experimental design for uncertainty reduction in gene regulatory networks
}

Roozbeh Dehghannasiri ${ }^{1,2}$, Byung-Jun Yoon ${ }^{1,2,3}$ and Edward R. Dougherty ${ }^{1,2^{*}}$

\section{Erratum}

During the production of this article [1], errors occurred in equations and algorithms. The Editorial Department of BMC Bioinformatics would like to apologise and inform its readers that an updated version is now available on the BMC Bioinformatics website.

\section{Author details \\ 'Department of Electrical and Computer Engineering, Texas A\&M University, College Station, TX 77843, USA. ${ }^{2}$ Center for Bioinformatics and Genomic Systems Engineering, Texas A\&M University, College Station, TX 77845, USA. ${ }^{3}$ College of Science and Engineering, Hamad bin Khalifa University (HBKU), Doha, Qatar.}

Received: 19 October 2015 Accepted: 2 December 2015

Published online: 14 December 2015

\section{Reference}

1. Dehghannasiri R, Yoon BJ, Dougherty ER. Efficient experimental design for uncertainty reduction in gene regulatory networks. BMC Bioinformatics. 2015;16 Suppl 13:S2.

\footnotetext{
* Correspondence: edward@ece.tamu.edu

'Department of Electrical and Computer Engineering, Texas A\&M University, College Station, TX 77843, USA

${ }^{2}$ Center for Bioinformatics and Genomic Systems Engineering, Texas A\&M University, College Station, TX 77845, USA
}

Submit your next manuscript to BioMed Central and we will help you at every step:

- We accept pre-submission inquiries

- Our selector tool helps you to find the most relevant journal

- We provide round the clock customer support

- Convenient online submission

- Thorough peer review

- Inclusion in PubMed and all major indexing services

- Maximum visibility for your research

Submit your manuscript at

www.biomedcentral.com/submit

\section{() Biomed Central}

